\title{
Cztery świadectwa święceń duchownych z diecezji krakowskiej z XV i XVI wieku'
}

Dotychczasowe studia nad święceniami kleru w Polsce średniowiecznej wyraźnie koncentrują się na duchowieństwie pochodzącym z czterech diecezji: gnieźnieńskiej, płockiej, przemyskiej oraz włocławskiej². Taki stan rzeczy podyktowany jest stanem zachowania źródeł - to właśnie w zasobach archiwalnych wskazanych biskupstw przetrwało najwięcej materiałów pozwalających na odtworzenie praktyki ordynowania kleru w okresie przedtrydenckim i zestawienie wykazów kandydatów, którzy w XV oraz pierwszej połowie XVI stulecia odebrali z rąk tamtejszych ordynariuszy bądź ich sufraganów niższe i wyższe ordines. Zdecydowana większość tych materiałów została w ostatnich latach wprowadzona do naukowego obiegu pod postacią regularnych edycji bądź wypisów ze źródeł zawierających imiona ordynowanych kleryków3;

1. Praca napisana w ramach projektu badawczego nr 11 H 18002986 ( "Najstarsza księga święceń polskiego duchowieństwa z lat 1514-1530"), finansowanego przez Narodowy Program Rozwoju Humanistyki.

2. Por. K. Kaczmarek, Święcenia duchowieństwa $w$ diecezji gnieźnieńskiej w latach 1482-1493, Poznań 2018, s. 7-13.

3. Zob. W. Kujawski, Wykazy święconych z najstarszej księgi akt działalności biskupów włocławskich (Kurozwęckiego i Przerębskiego - lata 1496-1511), "Archiwa, Biblioteki i Muzea Kościelne" 72 (1999), s. 23-112; A. Łosowska, Wykazy wyświęconych $w$ diecezji przemyskiej w pierwszej połowie XVI wieku, "Premislia Christiana" 16 (2014/2015), s. 201-250; K. Kaczmarek, Święcenia duchowieństwa przez biskupa włocławskiego Macieja Drzewickiego w latach 1516-1529, "Archiwa, Biblioteki i Muzea Kościelne" 104 (2015), s. 55-92; K. Kaczmarek, Duchowni ordynowani przez biskupa kujawskiego Jana Karnkowskiego w 1533 r., "Roczniki Humanistyczne" 64 (2016) z. 2, s. 5-24; K. Kaczmarek, Święcenia duchowieństwa przez biskupa Andrzeja Zebrzydowskiego w 1550 r., "Studia Włocławskie" 20 (2018), s. 575-590; K. Kaczmarek, Duchowni ordynowani wlatach 1539-1544 przez biskupów kujawskich: 
wyjątkiem jest najstarsza księga święceń diecezji płockiej, prowadzona w latach 1514-1530 przez tamtejszego sufragana, bp. Piotra Lubarta z Krakowa, która nie została dotąd wydana drukiem4.

Znacznie słabiej interesujące nas zagadnienie zostało rozpoznane w odniesieniu do kilku innych biskupstw należących do polskiej organizacji kościelnej, dla których z okresu średniowiecza nie dysponujemy podobnymi do wyżej przywołanych zestawieniami. Nie znamy żadnych średniowiecznych rejestrów święconego kleru z terenu diecezji poznańskiej i wrocławskiej5 zaś z diecezji krakowskiej mamy z tego okresu wyłącznie dwa bardzo krótkie wykazy akolitów wyświęconych w latach 1473-1475 przez Jana Rzeszowskiego, które zostały wpisane do księgi jego czynności biskupich ${ }^{6}$. Badając zagadnienie święceń kleru w tych diecezjach, trzeba zatem sięgać do innych źródeł, wśród których wyróżniają się tzw. świadectwa święceń (litterae formatae), wydawane przez biskupów ordynariuszy bądź ich sufraganów na prośbę zainteresowanych duchownych.

Średniowieczne littarae formatae zachowały się w największej liczbie w Archiwum Watykańskim, w którym jest przechowywana seria kilkunastu

Łukasza Górkę i Mikołaja Dzierzgowskiego, „Studia Gnesnensia” 31 (2017), s. 123143; K. Kaczmarek, Święcenia duchowieństwa w diecezji gnieźnieńskiej..., dz. cyt., s. 173-266; K. Kaczmarek, Święcenia duchowieństwa przez biskupa krakowskiego Jana Rzeszowskiego (†1488), "Folia Historica Cracoviensia" 18 (2012), s. 143-165; K. Kaczmarek, Święcenia duchowieństwa we Włocławku w 1516 r., "Zapiski Historyczne" 78 (2013) z. 4, s. 103-117; K. Kaczmarek, Zakonnicy na wykazach święconych z księgi arcybiskupa gnieźnieńskiego Zbigniewa Oleśnickiego (1482-1493), w: Wielkopolska - Polska - Czechy. Studia z dziejów średniowiecza ofiarowane Profesorowi Bronisławowi Nowackiemu, red. Z. Górczak i J. Jaskulski, Poznań 2009, s. 297-315; K. Kaczmarek, Święcenia zakonników w diecezji płockiej w I połowie XVI wieku, "Roczniki Historyczne" 77 (2011), s. 103-148; K. Kaczmarek, Święcenia zakonników w diecezji kujawskiej w I połowie XVI wieku, "Roczniki Humanistyczne" 62 (2014) nr 2, s. 5-27.

4. Biblioteka Zakładu Narodowego im. Ossolińskich we Wrocławiu, rkp. 4874 I: Matrica ordinacionis presbiterorum et clericorum per reverendum olim patrem dominum Petrum Dei gracia episcopum Lacedemonensem, achidiaconum, suffraganeum et canonicum Plocensem ab anno Domini 1515 usque ad M.D.XXX.

5. Zob. A. Gąsiorowski, Święcenia w diecezji kujawskiej na przełomie XVi XVI wieku, "Roczniki Historyczne" 67 (2001), s. 82; por. także S. Jujeczka, Wstęp, w: Katalog duchowieństwa diecezjalnego i zakonnego na podstawie ksiag święceń biskupów wrocławskich 1650-1810/12, oprac. S. Jujeczka, ks. H. Gerlic, W. Könighaus, Wrocław 2014, s. 33.

6. Archiwum Kurii Metropolitalnej w Krakowie, rkp. Acta Episcopalia III, fol. 87v i 105r. Por. K. Kaczmarek, Święcenia duchowieństwa przez biskupa krakowskiego Jana Rzeszowskiego..., dz. cyt., passim. 
samodzielnych ksiąg z lat 1425 - 1524, zawierających świadectwa duchownych, którzy tonsurę oraz wyższe i niższe ordines przyjęli podczas wizyty w Rzymie ${ }^{7} ;$ wśród nich znajdują się także klerycy z diecezji należących do polskiej organizacji kościelnej ${ }^{8}$. W rodzimych realiach materiałów takich zachowało się znacznie mniej, są też one dużo bardziej rozproszone. Antoni Gąsiorowski słusznie zauważył, że większość z nich zachowała się pod postacią kopii oryginalnych dokumentów, ingrosowanych do akt biskupich lub innych ksiąg kościelnych ${ }^{9}$; ich odnalezienie wymaga zatem żmudnych kwerend archiwalnych, obejmujących średniowieczny materiał dyplomatyczny, akta czynności biskupich oraz księgi konsystorskie. Zasięg poszukiwań niezbędnych do zinwentaryzowania tych materiałów jest tak duży, że - jak dotąd - w literaturze przedmiotu wzmiankowano tylko nieliczne "formaty": najwięcej takich materiałów odnaleziono w spuściźnie rękopiśmiennej pozostałej po diecezji wrocławskiej i gnieźnieńskiej ${ }^{10}$, a także po biskupstwach położonych na terenie państwa Zakonu Krzyżackiego w Prusach i Ziemi Chełmińskiej"i; wydano

7. Zob. L. Schmitz, Die Libri Formatarum der Camera Apostolica, „Römische Quartalschrift" 30 (1916-1922), s. 451-472; Z. Hledíková, Libri formatarum - una fonte conosciuta ma non scoperta, "Bolletino dell' Instituto Storico Ceco di Roma" 5 (2006), s. 35-60; Z. Hledíková, Libri formatarum, w: Per Saecula ad tempora nostra. Sborník prací k šedesátým narozeninám prof. Jaroslava Pánka, Sv. 1, uspořádali J. Míkulec i M. Polívka, Praha 2007, s. 69-77.

8. Osobną pracę na ich temat przygotowuje M. D. Kowalski, Święcenia polskich duchownych w Rzymie w XV wieku [w druku]; Panu Profesorowi Kowalskiemu składam w tym miejscu podziękowania za informację o powstającym artykule; ostatnio także Klerycy z ziem polskich, litewskich i pruskich święceni w Rzymie (XVI - pocz. $X X$ w.), oprac. S. Jujeczka na podstawie kwerendy rzymskiej wykonanej wspólnie z ks. Henrykiem Gerlicem, Wrocław 2018.

9. Zob. A. Gąsiorowski, Święcenia w diecezji kujawskiej na przełomie XV i XVI wieku..., dz. cyt., s. 100-101.

10. Por. W. Urban, Wykaz regestów dokumentów Archiwum Archidiecezjalnego we Wrocławiu, Warszawa 1970; W. Urban, Wykaz regestów dokumentów Archiwum Archidiecezjalnego we Wrocławiu, cz. 4, "Studia Historyczno-Teologiczne Śląska Opolskiego" [dalej: SHTŚO] 5 (1975), s. 317-361; cz. 5, SHTŚO 6 (1978), s. 323-351; cz. 6, SHTŚO 7 (1979), s. 353-388; A. Gąsiorowski, Święcenia w diecezji kujawskiej na przełomie XV i XVI wieku..., s. 103-104; K. Kaczmarek, Litterae formatae - średniowieczne świadectwa święceń duchownych z diecezji gnieźnieńskiej [w druku].

11. Materiały te opublikował częściowo A. Kolberg, Ein preussisches Formelbuch des 15. Jahrhunderts, "Zeitschrift für Geschichte und Altertumskunde Ermlands" 9 (1888), s. 273-328; cały tekst źródła wydał ostatnio R. Biskup, zob. Formularz z Uppsali. Późnośredniowieczna księga formularzowa biskupstw pruskich, komentarz i edycja R. Biskup, Toruń 2016. 
też drukiem pojedyncze świadectwa święceń duchownych z terenu diecezji włocławskiej oraz płockiej ${ }^{12}$.

Kwerenda przeprowadzona przy okazji studiów nad praktyką święceń duchowieństwa w późnośredniowiecznej Polsce pozwoliła na zidentyfikowanie w archiwach kościelnych kilku nieznanych dotąd literaturze przedmiotu świadectw święceń duchownych z diecezji krakowskiej wystawionych w drugiej połowie XV i pierwszej połowie XVI stulecia. Materiały te udało się odnaleźć w jednej z XV-wiecznych ksiąg konsystorza gnieźnieńskiego, pochodzących z tego samego okresu aktach krakowskiego oficjalatu oraz XVI-wiecznych księgach czynności biskupich dwóch ordynariuszy poznańskich: Jana Lubrańskiego i Jana Latalskiego. Najstarsze z interesujących nas świadectw zostało wystawione 20 września 1460 roku w Krakowie przez biskupa tytularnego Laodycejskiego i sufragana krakowskiego Jerzego. Czytamy w nim, że we wskazanym dniu hierarcha ten udzielił w krakowskim kościele Franciszkanów święceń subdiakonatu niejakiemu Andrzejowi (synowi Jakuba), pochodzącemu prawdopodobnie z Męciny Małej w diecezji krakowskiej³ i wskazał jako tytuł do tych święceń prawa Andrzeja do plebanii kościoła parafialnego w Słupcy, w diecezji gnieźnieńskiej ${ }^{14}$ Kolejne świadectwo zostało sporządzone w kancelarii biskupa krakowskiego Jana Rzeszowskiego - hierarcha oświadczył w nim, że w dniu 24 maja 1472 roku udzielił w katedrze krakowskiej niższych święceń bliżej nieokreślonej grupie duchownych i ordynował podczas tej uroczystości do stopnia akolitatu Grzegorza z Olkusza ${ }^{15}$. Następne "formaty" zachowały się w spuściźnie aktowej biskupów poznańskich. Najpierw - w dniu 28 marca 1517 roku - sufragan diecezji poznańskiej Wojciech z Sochaczewa oświadczył, że za zgodą biskupa krakowskiego udzielił w katedrze w Poznaniu święceń akolitatu Janowi (synowi Macieja) z Jakimowic w diec. krakowskiej ${ }^{16}$, zaś po upływie kilkunastu

12. Por. K. Kaczmarek, Nieznane świadectwa święceń Stanisława z Kowala w diecezji kujawskiej, "Zapiski Historyczne" 82 (2017) z. 4, s. 111-121; K. Kaczmarek, Trzy średniowieczne świadectwa święceń duchownych z diecezji płockiej [w druku].

13. Nie jestem do końca pewien identyfikacji tej miejscowości, bowiem druga część jej dwuczłonowej nazwy jest mocno wytarta i słabo czytelna - zob. Aneks, nr 1.

14. Archiwum Archidiecezjalne w Gnieźnie, rkp. Acta Causarum Consistorii Gnesnensis A 41, fol. 1r.

15. Zob. Archiwum Kurii Metropolitalnej w Krakowie, rkp. Acta Officialia III, fol. $125 \mathrm{r}-125 \mathrm{v}$.

16. Zob. Archiwum Archidiecezjalne w Poznaniu, rkp. Acta Episcopalia VI, fol. 24v. 
następnych lat (25 marca 1531 roku) bp Jan Latalski ordynował tego samego Jana Jakimowskiego do stopnia subdiakona ${ }^{17}$.

Przywołane świadectwa święceń zostały sporządzone za pomocą stosowanego przy okazji spisywania takich aktów formularza, znanego z innych tego typu zabytków. Każde z nich podaje informację o szafarzu święceń, datę oraz miejsce uroczystości wraz z nazwą świątyni, w której odbyła się celebra, stopień święceń, na który ordynowano daną osobę, a w przypadku duchownych przyjmujących subdiakonat - Andrzej (z Męciny Małej?) i Jan z Jakimowic - także tytuł do tych święceń. W przypadku pierwszych (akolitat) święceń Jana Jakimowskiego świadectwo odnotowuje też zgodę na ich przyjęcie poza granicą diecezji krakowskiej wydaną przez jej ówczesnego ordynariusza. Z czterech odnalezionych świadectw trzy zostały wydane w tzw. kanonicznych terminach święceń, które - jak wiadomo - przypadały w soboty "kwartalnych suchych dni", sobotę zwaną Sicientes oraz w Wielką Sobotę $^{18}$. Od reguły tej odstaje wyłącznie świadectwo Grzegorza z Olkusza - święcenia akolitatu otrzymał on w nietypowym terminie, to znaczy w niedzielę Trójcy Świętej, która w 1472 roku wypadała 25 maja. Fakt ten nie oznacza jednak złamania przez bp. Jana Rzeszowskiego zaleceń prawa kościelnego, ponieważ niższych święceń (a takie przyjął Grzegorz) można było udzielać w zasadzie przez cały rok (także w niedziele), choć uroczystości takie nie powinny mieć masowego charakteru. Nie wiadomo, jak liczna była grupa kandydatów do niższych święceń, która w maju 1472 roku stanęła przed Janem Rzeszowskim, nie ma jednak powodów wątpić, że biskup dochował wierności przywołanym wyżej zasadom. Skądinąd wiemy zresztą, że hierarcha ten udzielał święceń w terminach niedzielnych także w innych latach i uroczystości te zawsze gromadziły bardzo nieliczne grupy ordynandów ${ }^{19}$.

Trzy z odnalezionych "formatów" mówią o święceniu kandydatów w głównych kościołach wymienionych w nich diecezji, to znaczy w katedrach w Krakowie oraz Poznaniu. Odstaje od nich świadectwo Andrzeja (z Męciny

17. Zob. Archiwum Archidiecezjalne w Poznaniu, rkp. Acta Episcopalia VII, fol. 206v.

18. O terminach święceń zob. np. V. Davies, Clergy in London in the Late Middle Ages. A Register of Clergy Ordained in the Diocese of London Based on Episcopal Ordination Lists 1361-1539, London 2000, s. 16; J. A. Hoeppner Moran, Clerical Recruitment in the Diocese of York 136o-1530. Data and Commentary, "Journal of Ecclesiastical History" 34 (1983), s. 24-25; E. Doležalova, Svěcenci pražské diecéze 1395-1416, Praha 2010, s. 104-110.

19. Por. K. Kaczmarek, Święcenia duchowieństwa przez biskupa krakowskiego Jana Rzeszowskiego..., dz. cyt., s. 149-150. 
Małej?), który został akolitą w kościele krakowskich Franciszkanów. To interesująca okoliczność, bowiem z dotychczasowych badań nad praktyką święceń kleru w diecezjach polskiego Kościoła wynika, że biskupi zwykle zwoływali ordynandów do katedr lub kościołów ulokowanych w centrach kluczy majątkowych, które odwiedzali podczas zwyczajowych objazdów swych dóbr, stosunkowo rzadko natomiast gromadzili ordynowany kler w świątyniach klasztornych - źródła informują o święceniach, jakie biskupi gnieźnieńscy, przemyscy oraz włocławscy organizowali w kościołach dominikanów w Gdańsku, Lublinie i Piotrkowie, wiadomo też o uroczystości święceń celebrowanej w początkach XVI stulecia u franciszkanów w Gnieźnie ${ }^{20}$; wiemy wreszcie, że w kościele Braci Kaznodziejów w Krakowie ordynował duchownych wywodzący się z zakonu dominikańskiego sufragan krakowski Paweł ${ }^{21}$. Gdyby zestawić te wzmianki z wiadomościami o lokalizacji święceń w innych (należących do struktur diecezjalnych) kościołach, okazałoby się, że w takim wykazie obiekty należące do wspólnot klasztornych należą do zdecydowanej mniejszości. Na tej podstawie można by z kolei wyciągnąć wniosek, iż znane z ziem polskich lokalizacje uroczystości święceń odbiegają od tych, które znamy z innych krajów (na przykład Czech czy Anglii), gdzie biskupi bardzo chętnie gromadzili kandydatów do święceń właśnie w kościołach klasztornych $^{22}$. Nie da się jednak wykluczyć, że dalsze badania nad geografią święceń w poszczególnych diecezjach oparte na analizie świadectw poszczególnych duchownych pozwolą na wprowadzenie korekt do znanej z dotychczasowych studiów listy ośrodków oraz świątyń, w których gromadzili się chętni do przyjęcia poszczególnych ordines i umieszczenie w tym wykazie większej od zidentyfikowanej dotąd liczby kościołów klasztornych. Ciekawe jest także wspomniane w świadectwie Andrzeja wezwanie krakowskiej świątyni Braci Mniejszych - choć kościół ten występuje zwykle w źródłach z wezwaniem św. Franciszka, w "formatach" interesującego nas duchownego pojawia się informacja o odprawieniu uroczystości święceń in ecclesia Corporis Christi in monasterio fratrum minorum sancti Francisci. Na tej podstawie możemy

20. K. Kaczmarek, Święcenia duchowieństwa w diecezji gnieźnieńskiej..., dz. cyt., s. 44-51; A. Łosowska, Duchowni wyświęceni w Lublinie przez biskupa przemyskiego Macieja Drzewickiego (28 II 1506), "Archiwa, Biblioteki i Muzea Kościelne" 100 (2013), s. 248.

21. K. Kaczmarek, Nieznane świadectwa święceń Stanisława z Kowala w diecezji kujawskiej..., dz. cyt., s. 115 .

22. E. Doležalova, Svěcenci pražské diecéze 1395-1416, dz. cyt., s. 87-104; V. Davies, Clergy in London in the Late Middle Ages..., dz. cyt., s. 19-20. 
przyjąć, że święcenia w dniu 20 września 1460 roku odbyły się w północnej nawie franciszkańskiej świątyni, która po przebudowie w latach 1420-1436 otrzymała wezwanie Bożego Ciała (dziś jest to kaplica Męki Pańskiej), nadane zapewne w związku z jego nasilającym się w XV stuleciu kultem²3.

Trudno powiedzieć coś o dalszych losach i ewentualnych karierach kościelnych większości wymienionych w analizowanych świadectwach duchownych. Kompletnie anonimową postacią wydaje się na obecnym etapie badań Grzegorz z Olkusza, niemal nic nie wiemy też o kolejach życia Andrzeja (z Męciny Małej?). W odniesieniu do tego ostatniego wolno tylko podejrzewać, że nieznane bliżej trudności w osiągnięciu jakiegoś beneficjum lub innych stałych dochodów zmusiły go do opuszczenia macierzystej diecezji krakowskiej i szukania (zakończonego wszak powodzeniem) źródła utrzymania poza jej granicami. Z wymienionych w świadectwach osób największą karierę zrobił bez wąpienia Jan z Jakimowic. Już w 1518 roku, a więc zaraz po przyjęciu niższych święceń, spotykamy go w charakterze skarbnika w otoczeniu biskupa poznańskiego Jana Lubrańskiego ${ }^{24}$. W następnych latach Jan postąpił w szeregi kanoników sandomierskich i poznańskich, w tej ostatniej kapitule starał się nadto (ale bez powodzenia) o prałaturę archidiakona; był również sekretarzem biskupa krakowskiego Jana Latalskiego oraz kanclerzem nadwornym ordynariusza poznańskiego Sebastiana Branickiego ${ }^{25}$. Poza wspomnianymi kanoniami posiadał (i to w dużej liczbie) także inne beneficja kościelne: XVI-wieczne źródła wspominają go jako plebana w Obrazowie (1509, 1540-1542), Sulisławicach (1529), Ciążeniu i Lubiniu (1531), Kozłowie Biskupim (1541) oraz Żbikowie (1543/1544) ${ }^{26}$.

23. Zob. K. S. Rosenbaiger, Dzieje kościoła OO. Franciszkanów w Krakowie w wiekach średnich, Kraków 1933, s. 66-84 (Biblioteka Krakowska, t. 79); S. Skibiński, Pierwotny kościół franciszkanów w Krakowie, Poznań 1977, s. 12; w tej sprawie obszernie także C. Niezgoda, Kaplica Męki Pańskiej w kościele św. Franciszka z Asyżu w Krakowie, „W Nurcie Franciszkańskim" 1 (1987), s. 72-73.

24. K. Lutyński, Kościelna działalność Jana Lubrańskiego jako biskupa poznańskiego, "Kronika Miasta Poznania" 69 (1999) nr 2, s. 86.

25. K. Lutyński, Poznańscy prałaci i kanonicy w XVI w., "Saeculum Christianum" 1 (1994) nr 2, s. 152; J. Nowacki, Dzieje Archidiecezji Poznańskiej, t. 2: Archidiecezja Poznańska w granicach historycznych i jej ustrój, Poznań 1964, s. 96 i 305; J. Wiśniewski, Katalog prałatów i kanoników sandomierskich od 1186 do 1926 r., Radom 1925, s. 85 .

26. J. Nowacki, Dzieje Archidiecezji Poznańskiej..., dz. cyt., s. 512 i 518; także W. Kowalski, Jan Długosz a tzw. szlachecki antyklerykalizm w siedemnastowiecznej Rzeczypospolitej, w: Jan Długosz w kręgu badań historyków i literaturoznawców, red. T. Giergiel, Sandomierz 2017, s. 198-200; benedyktyni lubińscy upamiętnili zgon 
Przeprowadzona na potrzeby badań nad święceniami duchowieństwa z diecezji krakowskiej kwerenda pokazała, że akta tej diecezji (księgi biskupie i akta oficjalatu) są ubogie w interesujące nas informacje, niewiele danych na ten temat udało się też odnaleźć w analogicznych materiałach z innych diecezji. Nie sposób nawet porównywać ich do bardzo bogatego zasobu materiałów oświetlających zagadnienie święceń krakowskiego kleru w czasach nowożytnych ${ }^{27}$. Kilka przedstawionych w niniejszym przyczynku "formatów" duchownych z Krakowa i jego okolic przynosi co prawda skromny materiał do badań nad prozopografią krakowskiego kleru w dobie średniowiecza, ale w sytuacji wielkiego niedostatku takich danych z okresu przedtrydenckiego zasadne wydaje się wydobywanie z archiwalnych zasobów choćby najskromniejszych śladów praktyk ordynowania nowych zastępów duchowieństwa przez krakowskich ordynariuszy i ich sufraganów.

Jana Jakimowskiego notką w swym klasztornym nekrologu, zapewne właśnie z uwagi na trzymane przezeń probostwo w tej miejscowości - zob. Liber mortuorum monasterii Lubinensis ordinis sancti Benedicti, wyd. W. Kętrzyński, w: Monumenta Poloniae historica, t. 5, Lwów 1888, s. 644.

27. Por. J. Kracik, Księgi święceń i konsekracji jako źródło historyczne, "Notificationes e Curia Metropolitana Cracoviensi" 119 (1981) nr 7-9, s. 216-222. 


\section{ANEKS $^{28}$}

\section{Świadectwa święceń duchownych z diecezji krakowskiej}

z XV i XVI w.

1.

Kraków, $20 I X 1460$ r.

Jerzy, biskup tytularny Laodycejski i sufragan krakowski zaświadcza, że udzielił święceń subdiakonatu Andrzejowi, plebanowi w Słupcy w diec. gnieźnieńskiej.

Kop. Archiwum Archidiecezjalne w Gnieźnie, Acta Causarum Consistorii Gnesnensis A 41, fol. 1 r.

Tenor formate plebani Slupczensis. Jeorgius, Dei gracia episcopus Laodicensis, reverendissimi in Christo patris et domini domini Thome, eadem gracia episcopi Cracoviensis suffraganeus, significamus tenore presencium

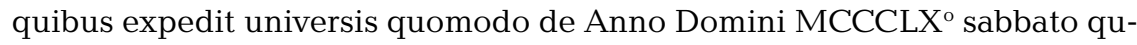
atuor temporum quo in ecclesia Dei Venite adoremus [decantatur] sacrosclericorum ordines in ecclesia Corporis Christi in monasterio fratrum minorum sancti Francisci solemniter celebrando, discretum Andream Jacobi de Minori Mecina ${ }^{a}$ Cracoviensis diocesis tunc in minoribus constitutus rite examinatum idonemuque repertum [ad certum] capelle sue in Slupcza Gneznensis diocesis ad gradus subdiaconatus divina nobis [gracia ad id] suffragante promovimus. Anno die et loco quibus supra, sigillo nostro [presentibus appenso].

a lekcja niepewna, słowo mocno wytarte

28. Przy edycji tekstów świadectw kierowałem się instrukcją wydawniczą dla źródeł średniowiecznych, zob. A. Wolff, Projekt instrukcji wydawniczej dla pisanych źródeł średniowiecznych do połowy XVI wieku, "Studia Źródłoznawcze" 1 (1957), s. $155-181$. 
Kraków, 24 V 1472 r.

Jan Rzeszowski, biskup krakowski zaświadcza, że udzielił święceń akolitatu Grzegorzowi z Olkusza

Kop. Archiwum Kurii Metropolitalnej w Krakowie, Acta Officialia III, fol. $125 \mathrm{r}-125 \mathrm{v}$.

Littera formate. Johannes, Dei gracia episcopus Cracoviensis significamus tenore presencium quibus expedit universis, quomodo de anno 1472 die dominica Sanctissimae Trinitatis ordines minores celebrando in ecclesia nostra Cracoviensi, discretum Gregor(em) Gmolanem ${ }^{a}$ Gregorii de Ilkusch clericum nostre diocesis ad gradum accolitatus rite examinatum idoneumque repertum promovimus et ordinamus divina nobis gracia ad in suffragante. In cuius rei testimonium sigillum nostrum presentibus est subappensum. Actum et datum Cracoviae in curia nostra episcopali, anno, die, loco quibus supra.

a lekcja niepewna: Gmolanem?, Gwolanem?

3 .

Poznań, 28 III $1517 \mathrm{r}$.

Wojciech z Sochaczewa, biskup tytularny Enneński i sufragan poznański zaświadcza, że udzielił święceń akolitatu Janowi z Jakimowic.

Kop. Archiwum Archidiecezjalne w Poznaniu, Acta Episcopalia VI, fol. $24 \mathrm{~V}$.

Ingrosatio formatus Jakymowski. $<$ Die secunda Aprilis $>^{a}$. Constitutus ad acta presencia personaliter discretus Joannes Mathie de Jakymovicze, clericus in minoribus ordinibus constitutus, cuius formatus sui petint eas per reverendissimum dominum episcopum ingrossari mandari et dominus mandavit ingrossari quarum litterarum tenor sequitur. Albertus Dei gracia episcopus Enensis et suffraganeus Posnaniensis significamus tenore presencium universis quibus expedit, quomodo de Anno Domini millessimo quingentesimo decimo septimo in ecclesia cathedrali Posnaniensi sabbato quo decantatur Sicientes venite ad aquas omnes sacros clericorum ordines celebrando dilectum nobis in Christo filium Joannis Mathie de Jakymowycze, 
clericus dioecesis Cracoviensis, de licencia sui dioecesani nobis per suas patentes litteras facta rite examinatum et idoneumque repertum ad gradus accolitatus gracia divina id ad suffragante nobis promovimus. In cuius rei testimonium sigillum nostrum presentibus est subappensum. Datum anno, die et loco quibus supra.

a nadpisane

4 .

Poznań, 25 III 1531 r.

Jan Latalski, biskup poznański zaświadcza, że udzielił święceń subdiakonatu Janowi Jakimowskiemu.

Kop. Archiwum Archidiecezjalne w Poznaniu, Acta Episcopalia VII, fol. $206 \mathrm{v}$.

Reverendissimus in Christo pater et dominus Joannes, Dei gracia episcopus Posnaniensis, sabbato quo cantatur Venite ad me sicientes 1531 quatuor temporum, omnes sacros clericorum ordines in ecclesia cathedrali Posnaniensi celebrando, venerabilem dominum Joannem Jakimowski, canonicum Sandomiriensem in Czrazim et Lubin plebanum, in sacros clericorum ordines subdiaconatus videlicet rite examinatum idoneumque repertum promovit et ordinavit. 


\section{Bibliografia}

Źródła

Archiwum Archidiecezjalne w Gnieźnie, rkp. Acta Causarum Consistorii Gnesnensis A 41.

Archiwum Archidiecezjalne w Poznaniu, rkp. Acta Episcopalia VI i VII.

Archiwum Kurii Metropolitalnej w Krakowie, rkp. Acta Episcopalia III.

Archiwum Kurii Metropolitalnej w Krakowie, rkp. Acta Officialia III.

Archiwum Państwowe w Poznaniu, sygn. Klasztor benedyktynów w Lubiniu 239.

Biblioteka Zakładu Narodowego im. Ossolińskich we Wrocławiu, rkp. 4874 I.

Formularz z Uppsali. Późnośredniowieczna księga formularzowa biskupstw pruskich, komentarz i edycja R. Biskup, Toruń 2016.

Klerycy z ziem polskich, litewskich i pruskich święceni w Rzymie (XVIpocz. $X X$ w.), oprac. S. Jujeczka na podstawie kwerendy rzymskiej wykonanej wspólnie z ks. Henrykiem Gerlicem, Wrocław 2018.

Kolberg A., Ein preussisches Formelbuch des 15. Jahrhunderts, "Zeitschrift für Geschichte und Altertumskunde Ermlands" 9 (1888), s. 273-328.

Liber mortuorum monasterii Lubinensis ordinis sancti Benedicti, wyd.

W. Kętrzyński, w: Monumenta Poloniae historica, t. 5, Lwów 1888, s. $585-652$.

\section{Opracowania}

Davies V., Clergy in London in the Late Middle Ages. A Register of Clergy

Ordained in the Diocese of London Based on Episcopal Ordination Lists 1361-1539, London 2000.

Doležalova E., Svěcenci pražské diecéze 1395-1416, Praha 2010.

Gąsiorowski A., Święcenia w diecezji kujawskiej na przełomie XVi XVI wieku, "Roczniki Historyczne" 67 (2001), s. 79-105.

Hledíková Z., Libri formatarum, w: Per Saecula ad tempora nostra, Sv. 1, uspořádali J. Míkulec i M. Polívka, Praha 2007, s. 69-77. 
Hledíková Z., Libri formatarum - una fonte conosciuta ma non scoperta, „Bolletino dell'Instituto Storico Ceco di Roma" 5 (2006), s. 35-60.

Hoeppner Moran J. A., Clerical Recruitment in the Diocese of York 136o1530. Data and Commentary, "Journal of Ecclesiastical History" 34 (1983), s. 19-54.

Jujeczka S., Wstęp, w: Katalog duchowieństwa diecezjalnego i zakonnego na podstawie ksiag święceń biskupów wrocławskich 1650-1810/12, oprac. S. Jujeczka, ks. H. Gerlic i W. Könighaus, Wrocław 2014, s. $25-76$.

Kaczmarek K., Duchowni ordynowani przez biskupa kujawskiego Jana Karnkowskiego w 1533 r., "Roczniki Humanistyczne" 64 (2016) z. 2, s. $5-24$.

Kaczmarek K., Duchowni ordynowani w latach 1539-1544 przez biskupów kujawskich: Łukasza Górkę i Mikołaja Dzierzgowskiego, „Studia Gnesnensia" 31 (2017), s. 123-143.

Kaczmarek K., Litterae formatae - średniowieczne świadectwa święceń duchownych z diecezji gnieźnieńskiej [w druku].

Kaczmarek K., Nieznane świadectwa święceń Stanisława z Kowala w diecezji kujawskiej, "Zapiski Historyczne" 82 (2017) z. 4, s. 111-121.

Kaczmarek K., Święcenia duchowieństwa przez biskupa Andrzeja Zebrzydowskiego w 1550 r., "Studia Włocławskie” 20 (2018), s. 575-590.

Kaczmarek K., Święcenia duchowieństwa przez biskupa krakowskiego Jana Rzeszowskiego (†1488), „Folia Historica Cracoviensia" 18 (2012), s. $143-165$.

Kaczmarek K., Święcenia duchowieństwa przez biskupa włocławskiego Macieja Drzewickiego w latach 1516-1529, "Archiwa, Biblioteki i Muzea Kościelne" 104 (2015), s. 55-92.

Kaczmarek K., Święcenia duchowieństwa w diecezji gnieźnieńskiej w latach 1482-1493, Poznań 2018.

Kaczmarek K., Święcenia duchowieństwa we Włocławku w 1516 r., "Zapiski Historyczne" 78 (2013) z. 4, s. 103-117.

Kaczmarek K., Święcenia zakonników w diecezji kujawskiej w I połowie XVI wieku, "Roczniki Humanistyczne" 62 (2014) nr 2, s. 5-27.

Kaczmarek K., Święcenia zakonników w diecezji płockiej w I połowie XVI wieku, "Roczniki Historyczne" 77 (2011), s. 103-148.

Kaczmarek K., Trzy średniowieczne świadectwa święceń duchownych z diecezji płockiej [w druku]. 
Kaczmarek K., Zakonnicy na wykazach święconych z księgi arcybiskupa gnieźnieńskiego Zbigniewa Oleśnickiego (1482-1493), w: Wielkopolska - Polska - Czechy. Studia z dziejów średniowiecza ofiarowane Profesorowi Bronisławowi Nowackiemu, red. Z. Górczak i J. Jaskulski, Poznań 2009, s. 297-315.

Kowalski M. D., Święcenia polskich duchownych w Rzymie w XV wieku [w druku].

Kowalski W., Jan Długosz a tzw. szlachecki antyklerykalizm w siedemnastowiecznej Rzeczypospolitej, w: Jan Długosz w kręgu badań historyków i literaturoznawców, red. T. Giergiel, Sandomierz 2017, s. $187-207$.

Kracik J., Księgi święceń i konsekracji jako źródło historyczne, "Notificationes e Curia Metropolitana Cracoviensi" 119 (1981) nr 7-9, S. 216-222.

Kujawski W., Wykazy święconych z najstarszej księgi akt działalności biskupów włocławskich (Kurozwęckiego i Przerębskiego - lata 14961511), "Archiwa, Biblioteki i Muzea Kościelne" 72 (1999), s. 23-112.

Lutyński K., Kościelna działalność Jana Lubrańskiego jako biskupa poznańskiego, "Kronika Miasta Poznania" 69 (1999) nr 2, s. 71-92.

Lutyński K., Poznańscy prałaci i kanonicy w XVI w., "Saeculum Christianum" 1 (1994) nr 2, s. 109-153.

Łosowska A., Duchowni wyświęceni w Lublinie przez biskupa przemyskiego Macieja Drzewickiego (28 II 1506), "Archiwa, Biblioteki i Muzea Kościelne" 100 (2013), s. 245-264.

Łosowska A., Wykazy wyświęconych $w$ diecezji przemyskiej w pierwszej połowie XVI wieku, "Premislia Christiana" 16 (2014/2015), s. 201-250.

Niezgoda C., Kaplica Męki Pańskiej w kościele św. Franciszka z Asyżu w Krakowie, „W Nurcie Franciszkańskim" 1 (1987), s. 71-90.

Nowacki J., Dzieje Archidiecezji Poznańskiej, t. 2: Archidiecezja Poznańska w granicach historycznych i jej ustrój, Poznań 1964.

Rosenbaiger K. S., Dzieje kościoła OO. Franciszkanów w Krakowie w wiekach średnich, Kraków 1933, s. 66-84 (Biblioteka Krakowska, t. 79).

Schmitz L., Die Libri Formatarum der Camera Apostolica , "Römische Quartalschrift" 30 (1916-1922), s. 451-472.

Skibiński S., Pierwotny kościół franciszkanów w Krakowie, Poznań 1977.

Urban W., Wykaz regestów dokumentów Archiwum Archidiecezjalnego we Wrocławiu, Warszawa 1970. 
Urban W., Wykaz regestów dokumentów Archiwum Archidiecezjalnego we Wrocławiu, cz. 4, "Studia Historyczno-Teologiczne Śląska Opolskiego" 5 (1975), s. 317-361; cz. 5, SHTŚO 6 (1978), s. 323-351; cz. 6, SHTŚO 7 (1979), s. 353-388.

Wiśniewski J., Katalog prałatów i kanoników sandomierskich od 1186 do 1926 r., Radom 1925.

Wolff A., Projekt instrukcji wydawniczej dla pisanych źródeł średniowiecznych do połowy XVI wieku, „Studia Źródłoznawcze" 1 (1957), s. $155-181$. 


\section{Abstrakt}

Krzysztof Kaczmarek

Cztery świadectwa święceń duchownych

z diecezji krakowskiej z XV i XVI wieku

Słowa kluczowe:

święcenia,

duchowieństwo,

diecezja

krakowska,

XV-XVI wieku

Z terenu średniowiecznej diecezji krakowskiej posiadamy niewiele materiałów pokazujących praktykę święceń tamtejszego duchowieństwa. Z wyjatkiem dwóch krótkich wykazów akolitów ordynowanych przez bp. Jana Rzeszowskiego nie znamy też żadnych imiennych wykazów duchownych wyświęconych przez tamtejszych ordynariuszy i sufraganów. Z tego względu w badaniach nad święceniami kleru w tej diecezji warto sięgać do zapoznanych w dotychczasowych badaniach świadectw święceń poszczególnych duchownych. Kwerenda przeprowadzona w aktach biskupich i księgach konsystorskich kilku diecezji należących do polskiej organizacji kościelnej późnego średniowiecza pozwoliła na odnalezienie świadectw trzech duchownych z diecezji krakowskiej z lat 1460 - 1531: Andrzeja (prawdopodobnie z Męciny Małej), Grzegorza z Olkusza oraz Jana z Jakimowic. Zawartość tych materiałów ma znaczenie dla studiów nad prozopografią krakowskiego kleru w XV i pierwszej połowie XVI wieku. 


\section{Abstract}

Krzysztof Kaczmarek

Four Certificates of Holy Orders Taken

by Clerics from the Krakow Diocese

There are few records showing the practice of the holy orders taken by local clergy in medieval Krakow diocese. With the exception of two short lists of acolytes ordained by bishop Jan Rzeszowski, we do not have any name lists of clergymen ordained by local ordinaries and suffragans. Consequently, studies on the holy orders of clergy from the diocese should refer to certificates of the holy orders bestowed upon individual clerics identified in studies to date. The archival search, performed in bishops' files and consistory books from several dioceses belonging to late medieval Polish church organization, led to the retrieval of certificates of three clergymen from the Krakow diocese from the years 1460-1531: Andrzej (probably from MęcinaMała), Grzegorz from Olkusz and Jan from Jakimowice. The content of the certificates is of significance for studies on the prosopography of the Krakow clergy in $15^{\text {th }}$ and mid- $16^{\text {th }}$ century.

Keywords: certificate, holy orders, Krakow diocese, $15-16^{\text {th }}$ century 